\title{
財務諸表を用いたわが国の民間病院の経営状況の分析 (1982-1991年)
}

松田晋哉，村田洋 ${ }^{2}$

'産業医科大学公衆衛生学教室

産業医科大学産業生態科学研究所 産業保健経済学教室

要旨：わが国の民間病院の経営状況を知る目的で，社会福祉・医療事業団の資料をも とに，同事業団が貸付を行った民間病院の財務分析を行った。その結果，わが 国の民間病院の経営状況は，成長性，効率性は低いレベルでの定常状態にある が，経営状況は比較的安定していると考えられた。しかし、費用の効果性が伸 び悩むとともに，収益性が悪化しており，特に資本の回転率が低い，すなわち 投下資本に無駄が生じてきていることが明らかとなった．損益分岐点分析でも この点は明らかであり，近年損益分岐点比率は上昇（すなわち，経営安全率は 減少）しており，何らかの短期的変動要因で医業収益が $5 \%$ 低下寸ると平均值 以下の民間病院は赤字転落するという厳しい経営状況の実態が明らかとなった。

（1996 年 2 月 15 日 受付， 1996 年 4 月 22 日受理）

は じめに

来るべき高齢社会に対処するためにわが国 では年金制度改正，介護保険の導入等大規模 な社会保障制度の見直し作業が進められてい る. 特に，介護保険の導入は財政面での医療 と福祉の総合化を意味するものであり，わが 国の社会保障体系の今後の方向性を考える上 で重要な契機となるものである。1994 年の 21 世紀福祉ビジョンでは今後の社会保障体 系の基本理念として，「措置から契約へ」と いう基本理念を示した上で，現在 $5: 4: 1$ で配分している年金，医療，福祉の財源比率 を 5：3：2にすることを明記している [1]. すなわち，高齢化の進展と年金制度の成熟化 に伴い年金支出が今後急増していく状況と新 ゴールドプランに示した保健福祉サービスの 数值目標とを考慮すると, 今後医療費の増加
する余地はなく，むしろ社会的入院で代表さ れる要介護高齢者に対する医療費を福祉の財 源の枠組みに再配分することで医療費の増加 を押さえこむことが今後の保健医療政策の一 つの主要な柱となっていくと予想される。こ のような方向性はすでに老人保健法制定以後 の各種の法改正の中に読み取ることができる。 例えば，医療法の改正による老人保健施設の 医療施設としての再定義, 療養型病床群の定 義，および医療提供の場としての在宅の位置 ゔけの明確化は，施設から在宅への方向性と 施設に抢いては急性疾患対応から慢性疾患対 応への構造転換を明示するものである。そし て，このような構造転換は老人病院における 包括化医療費や看護基準別および対入院患者 老人収容率別の診療報酬の設定，あるいは在 宅医療に厚く配分した診療報酬の改定など， 診療報酬制度を具体的な誘導策として展開さ 
れてきている。しかし，このような財政面を 全面に出した政策誘導は必ずしも，公共資本 としての医療制度の最適化と合致するもので はなく，わが国の診療報酬制度の在り方には 医師会のみならず経済学者からの批判も多い [2]。このような医療経済政策により，わ が国の民間病院の経営状況は近年著しく悪化 して抢り，例えば，1993 年の全国民間病院 緊急経営状況調査によると, 全体の $30 \%$ が 赤字経営の状況にある [3]. 特に，わが国 の民間病院の主流を占める 200 床以下の病 院で近年の経営状況の悪化は著しく，こうし た病院は老人病院，老人保健施設といった療 養型施設への構造転換，あるいは閉院の選択 を迫られている。このような状況の原因の一 つに社会的ニーズを軽視したこれまでの病院 経営の在り方があることは疑いのないところ であり，平成 6 年度の国民医療年鑑でも医 業経営の近代化の必要性が強調されている [4]. 特に，折からのバブル経済期に，第 一次医療法改正をうけて全国的に生じた「駆 けこみ増床」あるいは株式投資・不動産投資 などによって, 経営の悪化した病院について は，ある意味で同情の余地はないともいえる。 しかし，多くの良心的な民間病院が現行の診 療報酬制度下で経営が成り立たなくなってき ていることも事実である。もし，社会的にみ て適切な医療サービスの提供主体が現行の診 療報酬制度で経営が成り立たないのであれば， その制度そのものを改正することは当然のこ とといえる。しかし，その前段階として事業 体の社会的・経営学的適切性が社会から評価 される必要がある。そのためには，病院の経 営状況を示す資料が開示され，現状について 周知される必要がある。公立病院については 地方公営企業年鑑などからその経営状況を知 ることができるが，わが国の場合，各医療法 人が病院会計準則に基づいて作成し，県に提 出する財務諸表は非公開であり，それを直接 分析することは現在のところ不可能である.
そこで，本論文では社会福祉・医療事業団が 貸付を行った民間病院について作成・公表し ている剘務諸表をもとに，わが国の民間病院 の経営状況の動向について財務分析を行った 結果について報告すると同時に，地域医療シ ステムの構築に扔ける財務諸表分析の有用性 とその活用の必要性について論述する。

\section{資料および方法}

社会福祉・医療事業団（以下，事業団）は 各年度ごとに貸付を行った民間病院について の財務諸表（貸借対照表，損益計算書）をま とめ, 経営分析参考指標としてそれを公表し ている。この参考指標には，年次ごとの貸借 対照表および損益計算書の各項目の平均值が 病院の種別（一般病院・精神病院）に揭載さ れている。本研究では，そのうち 1982 年か ら 1991 年の一般病院の平均值を使用し，そ れをもとに財務分析を行った [5]。ただし， 本分析で用いた資料は各年度で対象病院が必 ずしも同一ではなく，また原資料には個々の 医療機関の特性の変化を分析するための詳細 な資料も欠いている。したがって本分析結果 の解釈とその一般化には注意が必要である。

しかし，事業団の貸付は一定の貸付条件を満 たしたもののみが対象となるため，分析対象 となる病院の財政的特徵は年次を通してほほ 均一であると考えられ，したがって，経時的 変化の定性的分析を行うことには問題がない と考えられる。

次に，貸借対照表と損益計算書について病 院会計準則に基づいて簡単に説明する。貸借 対照表（Balance Sheet）は，事業年度末の財 政状態，すなわち事業体が資金をどのように 調達し，どのように運用しているのかを表わ すものである。資金の運用状態を表わすのが 資産の部で，流動資産（Circulating assets）, 固定資産 (Fixed assets), 繰延資産 (Defered assets）に大別される。「流動資産」と は現金および預金，医業未収金，受取手形， 
たな卸資産（医薬品，給食用材料等）などの 1 年以内に資金化される資産と販売に関する 資産である。「固定資産」は建物，機械装置， 土地などの「有形固定資産」と，借地権，電 話加入権などの「無形固定資産」，および投 資有価証券，長期貸付金等の「その他の資 産」の 3 種類が区別される。 また，「繰延資 産」には創立費，開業費等が含まれる。次に， 資金の調達状態を表わすものが負債 (Debt) の部 (他人資本) と資本 (Capital) の部 （自己資本）であり，負債は 1 年以内に返済 しなければならない「流動負債 (Current liability)」と返済期限が 1 年を超える「固定 負債 (Fixed liability)」に区別され，資本は

「資本金 (Capital stocks)」に属するものと 「剩余金（Surplus）」に属するものに区分さ れる、「流動負債」には経常的な活動によっ て生じた買掛金，支払手形およびその他 1 年 以内に期限の到来する債務 (未払法人税等) が含まれる。「固定負債」には長期借入金や その他支払期限の到来が 1 年を超える債務, および退職給与引当金などが含まれる，資本 のうち「資本剩余金」については国庫等補助 金，指定寄付金，贈与剩余金が含まれ，「利 益剩余金」には積立金および当期未処分利益 が含まれる。

次に損益計算書 (Profit and Loss Statement）とは事業体（病院）の経営成績を明 らかにするために，一定期間に属するすべて の収益とこれに対応するすべての費用とを記 載して医業活動から生ずる「医業利益 (Medical profit)」を表示し，これに医業外 活動から生ずる利益を加えて「経常利益

(Current profit)」を示し，さらにこれに特 別損益に属する項目を加減して「当期純利益

（Net profit）」を表示するものである.

上記 2 つの財務諸表の各項目の数值をも とに古典的な財務分析に用いられる以下の指 標を算出し, 安定性, 成長性, 収益性, 生産 性，費用の効果性，損益の状況の当該期間に
おける動向に着目して解析を行った。なお， 指標の計算式および基準值については付録お よび引用文献 $[6,7]$ を参照されたい.

1. 安定性指標 (Stability)

1）自己資本比率 (Equity to Capital ratio) : 総資本に占める自己資本の割合を示す比率 で，調達した資金の安定性を示す，自己資本 は返済義務のない資本であるから，この比率 が高いほど安定性は高いといえる。なお，医 療法施行規則では病院の自己資本比率は $20 \%$ 以上であることが定められている。

2）固定費率（Fixed asset ratio）：固定資産 と資本の比率で固定資産投資の安全性をみる。 固定資本投資が自己資本の範囲内であれば返 済義務はなく，資金繰りの面で安全といえる。 理想的には $100 \%$ 以下とされる.

3) 固定長期適合率 (Fixed asset to Capital and Fixed liability ratio）：固定資産と資本掠 よび固定負債との比率で固定資産投資の安全 性をみる。100％以下であれば設備投資資 金を長期の借り入れで賄っていることを意味 し，固定資産に対する過大な投資がないこと を意味する。

4）流動費率（Current ratio）：1 年以内に 資金化できる流動資産と返済しなければなら ない流動負債の比率で，支払能力をみる指標 である。理想的には $200 \%$ 以上とされるが， $120 \%$ あれば安全とされる。

2. 成長性指標 (Growth rate)

5）1床あたり医業収益増加率 (Annual growth rate of revenue per bed）：前期に比 した医業収益の伸び率を示す指標で，医療活 動の全体的な増加（成長）を示し，高いほう がよいとされる。

6）職員一人あたり医業収益増加率（Annual growth rate of revenue per worker) : 前期 に比した職員一人あたりの医業収益の伸び率 を示す指標で，一人あたり生産性の増加（成 
長)を示し，高いほうがよいとされる。

3. 収益性指標 (Profitability)

7）総資本医業利益率（Return on assets）: 投下された総資本に対し，獲得された医業利 益の割合を示す指標で，病院の経営能率を示 している。一般事業体の場合にはこの率が高 いことが望まれるが，病院の場合には提供す るサービスの質の問題との関係もあり，一概 にこの率が高いほどよいとはいえない。従っ て, 通常は以下の医業収益対医業利益率と総 資本回転率とに分解されて検討される。

8) 医業収益対医業利益率 (Rate of return to Revenue）：医業収益の何\%の利益が得ら れたかを示す指標で, 医療活動, 購買活動の 効率を指し，高いほうがよいとされる。

9）総資本回転率（Total assets turn-over） : 総資本の投下によりどれだけの医業収益を あげたかという資産の生産性を示す指標で, 一般的には高いほどよいとされる。総資本回 転率が低い場合には，一般的に過大投資の状 態を示していると考えられる。一方，医業利 益率が平均的で回転率が高い場合は，施設設 備の老朽化している場合などが考えられ，他 の指標とともに判断される必要がある。

\section{4. 生産性指標 (Productivity)}

10）稼働病床 1 床あたり入院収益（Inpatient revenue per bed）：1床あたりの入院 収益を示す指標で高いほうがよいとされる。

11）職員一人あたり医業収益（Medical revenue per worker)：職員 1 人あたりの医業収 益を示す指標で高いほうがよいとされる。一 般的には，職員一人あたり年間給与の 2 2.5 倍が目安である。

12) 粗付加価值率 (Added value rate) : 病 院の医業収益のうち，その病院により新たに 作り出された付加価值の割合を示守指標で, 過去実績との比較で評価される。付加価值と は病院によって新たに付け加えられた価值の
ことで，本分析では集計法によりそれを計算 ᄂ, 付加価値 $=$ 医業費用一医療材料費一給食 材料費一経費とした。

13）労働分配率（Labour's relative share）: 付加価值のうち，労働の対価として配分され た人件費の割合で，人件費負担の度合をみる 指標である，過去実績および業種平均との比 較でその高低が判断される。ちなみに，わが 国の全産業平均では約 $52 \%$ （1993 年：以 下同じ)，製造業では約 $58 \%$ ，非製造業で は約 $45 \%$ \%゙る。

5. 費用の効果性指標 (Efficiency of cost) 14）人件費率 (Ratio of personnel cost to Total cost）：医業収益に占める人件費の割合 を示す指標で，病院の場合には一般的に 50 \%以下が望ましいとされている。ちなみに， 他業種で人件費が高いとされている運輸や通 信でもこの值は $35 \%$ 程度である。

15）医療材料費率（Ratio of medical material cost to Total cost）: 医業収益に占める医療材 料費の割合を示す指標で，医薬品と診療材料 費別，および診療科別にその適否を判断する。 16）給食材料費率（Ratio of meal material cost to Total cost）：医業収益に占める給食材 料費の割合を示す指標である。

17) 経費率 (Ratio of general cost to Total cost）：医業費用から人件費，材料費，減価 償却費を除いたものが医業収益に占める割合 を示す指標で，検查・給食等の外注委託費， リース料，研究研修費などが含まれる。

18）減価償却費率 (Ratio of depreciation to Total cost）：医業収益に占める減価償却費の 割合を示す指標で, 建物や保有機器の構成押 よび経過年数からその適否を判断する。

6. 損益分岐点分析 (CVP analysis)

19）限界利益率（Marginal income ratio）: 医業収益から变動費を差し引いた利益を限界 利益といい，医業収益に対する限界利益の割 
合を限界利益率という。この指標は事業の採 算性の検討に有用である。なお，変動費とは 販売量・生産量に応じて比例的に増減して発 生する費用で，材料費，外注費などが該当す る，本分析では，藤原に従って勘定科目法を 用い [8], 医療材料費, 給食材料費のみを 変動費として分析に用いた。

20）変動費率（Variable income ratio）：医 業収益に占める変動費の占める割合を示す指 標である。

21）損益分岐点費率（Profit-volume ratio）： 売上高と費用が同額で，損益ゼロの状態とな る採算点を損益分岐点といい，その状態にお ける医業収益を損益分岐点医業収益という。

そして，この損益分岐点医業収益を医業収益 で割った率を損益分岐点比率といい, 経営の 安全度を分析する．損益分岐点比率が 100 \%を超える事業体は費用を収益で回収できて いない，すなわち赤字経営であることを示し ている.

22）経営安全率（Margin of safety ratio）: 100 一損益分岐点比率（\%）で計算される 指標で, 収益の変動に対する事業体の経営の 安全性を示す。

\section{結}

果

1. 貸付対象病院の一般的特徴の経時的変化 まず，貸付対象病院数をみると，1988 年 から 1989 年にかけていったん上昇している が，1982 年から 1991 年の全期間では半減 しているのが特徽的である。平均病床数は 1989 年まで増加した後, 減少傾向にある。 病床利用率は全期間を通じて $85 \%$ 前後で安 定している．入院患者／外来患者割合は全体 的には 1982 年の 1.6 から 1991 年の 1.5 へと減少傾向にあり，わが国の病院経営が外 来に強く依存しているという指摘を裏付ける ものである。人的資源をみると看護職・介護 職，医療職が増加傾向にあるのに対し，その 他職員が 1989 年以降減少傾向にある。この
ことは，経費節約を目的とした清掃・給食の 外注化，あるいは一部の病院でみられる事務 部門の別会社化の動向の反映であると考えら れる。また，医療職の増加傾向については非 常勤の医師の増加が大きいことにも注意して おく必要がある。

2. 財務諸表分析結果の経時的変化

1）安定性

まず，第一の特徴としては観察期間におい て自己資本比率が $24.2 \%$ から $14.5 \%$ へ 10 ポイントも低下していることがあげられる. 特に, 1987 年以降の減少は大きく, 貸借対 照表の 1 床あたりの資本額でも 1710 千円か ら 1330 千円へと, $22 \%$ も減少している. 固定資本比率は観察期間の 10 年間で 260.3 \%から $452.3 \%$ へと約 2 倍の増加率を示し ているが，固定長期適合率が 80 \%台で安定 していることから，固定資産投資は長期の借 り入れで賄われており，固定資本への投資は 概ね安全圈内にある。流動比率は1990 年に $128 \%$ という值を示しているが，概ね 140 から $150 \%$ 台で安全圈内にある.

2) 成長性

1 床あたり医業収益増加率, 職員 1 人あた り医業収益増加率ともに，5年間の平均増加 率でみると $102 \%$ 前後で安定している。

3）収益性

まず，総資本医業利益率をみると，1985 年に $4.5 \%$ とピークとなった後急減し, 1992 年には $1.2 \%$ となっている。 その内訳 をみると，医業収益対医業利益率，総資本回 転率共に同期間に減少しており，資本効率に 無駄が生じてきていることが強く示唆される。 4）生産性

「成長性」の指標である1床あたり医業 収益増加率, 職員 1 人あたり医業収益増加 率の経時的変化からも明らかなように, 収益 からみた病院の生産性は観察期間でほとんど 変化がない. 粗付加価值率でみると 1986 年 
以降減少傾向が認められるが, 労働分配率は 逆に同期間に増加傾向にある。このことは単 位サービスあたりの収益が減る一方で，人件 費率は上昇していることを示している。

5）費用の効果性

観察期間における各指標の動向をみると， 人件費率が上昇傾向，医療材料費率は減少傾 向, 給食材料費率は一定，経費率は増加傾向， 減価償却費率は 1990 年, 1991 年が約 18 \%とそれ以前より高い值を示している。

6) 損益分岐点分析

損益分岐点比率の動向をみると, 1985 年 まで減少傾向だったものが，以後増加傾向に 転じ 1991 年実績では $95.6 \%$ になってい， 経営安全率でみると $4.4 \%$ に減少している。

\section{考察}

本研究は事業団が貸付を行った民間病院の 財務諸表（損益計算書、貸借刘照表）をもと に標準的な財務諸表分析を行ったものである が、使用した資料は各年度の貸付対象施設の 平均值であり，したがって、分析結果につい て個々の医療機関の実態に帰って検討するこ

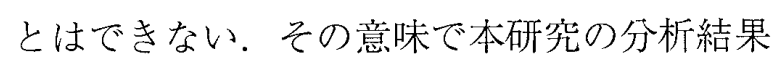
は当該期間のわが国の民間病院の一般的な経 営状況の経時的変化を定性的ないし半定量的 に評価しているに過ざないという制限がある。 そのために以下の考察においては，近年のわ が国の医療機関の経営環境の変化について記 述した他の資料等も適宜利用しながら, 結果 の考察を行う.

本研究の分析結果から分析対象となった民 間病院の経営状況の動向を要約すると, 成長 性，効率性は低いレベルでの定常状態にある が，経営状況は比較的安定しているといえる。 しかしながら，資本の内訳をみると自己資本 比率は低く，長期の借り入れという比較的安 全な他人資本に依存した安定性であることは 注意が必要である。また, 費用の効果性が伸 び悩む一方で，収益性が悪化しており，特に
資本の回転率が低い，すなわち投下資本に無 駄が生じていることが経営上の大きな解決課 題として浮上してきている。損益分岐点分析 でもこの点は明らかであり, 近年損益分岐点 比率は上昇（すなわち, 経営安全率は減少) しており，何らかの短期的変動要因で医業収 益が $5 \%$ 低下すると平均值以下の民間病院 は赤字転落することになる，本研究で用いた 資料にある民間病院が比較的経営状況のよい 施設であることを考慮すると, 多くの民間病 院の実態はより深刻なものであると予想され る. 実際，1993 年の厚生省民間病院経営緊 急調査によると赤字病院は約 $30 \%$ で，しか もその数は経時的に増加している。特に, 大 都市の医療法人では赤字病院の割合が $50 \%$ に達しており，厳しい状況が報告されている [3].

平成 5 年度の「医療経済実態調査」によ ると, 建築年代別にみた民間病院の主たる建 物の分布は，1970 年までに建設された病院 が約 $25 \%, 1971$ 年から 1980 年に建設さ れたものが約 $30 \%$ となっている [9]，施設 の建て替えが築後 30 年程度とすると, すで に1000 以上の民間病院がその時期に達して いると考えられ，したがってその需要に応じ て貸付件数も増加すると予想されるが, 実際 には各病院の投資意欲は冷え込んでおり，実 際の着工件数は伸び悩んでいる. Table 1 の 事業団による貸付対象病院数の減少もこうし た状況を反映しているものと考えられる.

こうしたわが国の民間医療機関の経営状況 の覀化の要因としては種々のものが考えられ るが,ここでは川㴊に倣い病院経営に関する 内部要因と, 病院に関連する外部環境要因に 分類して検討してみたい [10]。まず，外部 環境要因としては病院が直接関係する4つの 市場環境（医療サービス提供市場, 労働市場, 資本市場, 医療材料等の購買市場), 医療行 政をめぐる政治的環境，そして医療をめぐる 一般住民の考元方といった社会的・文化的環 


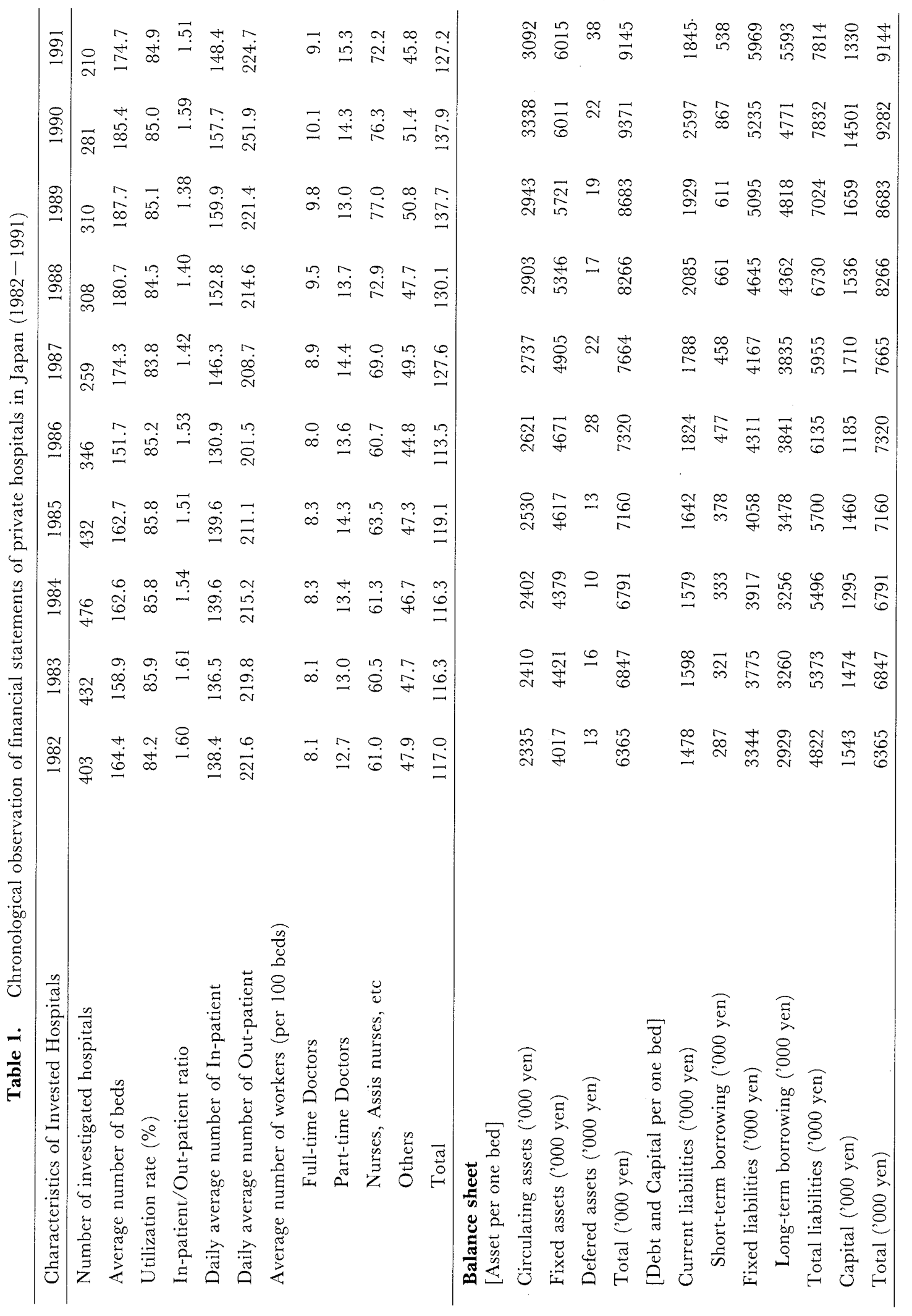




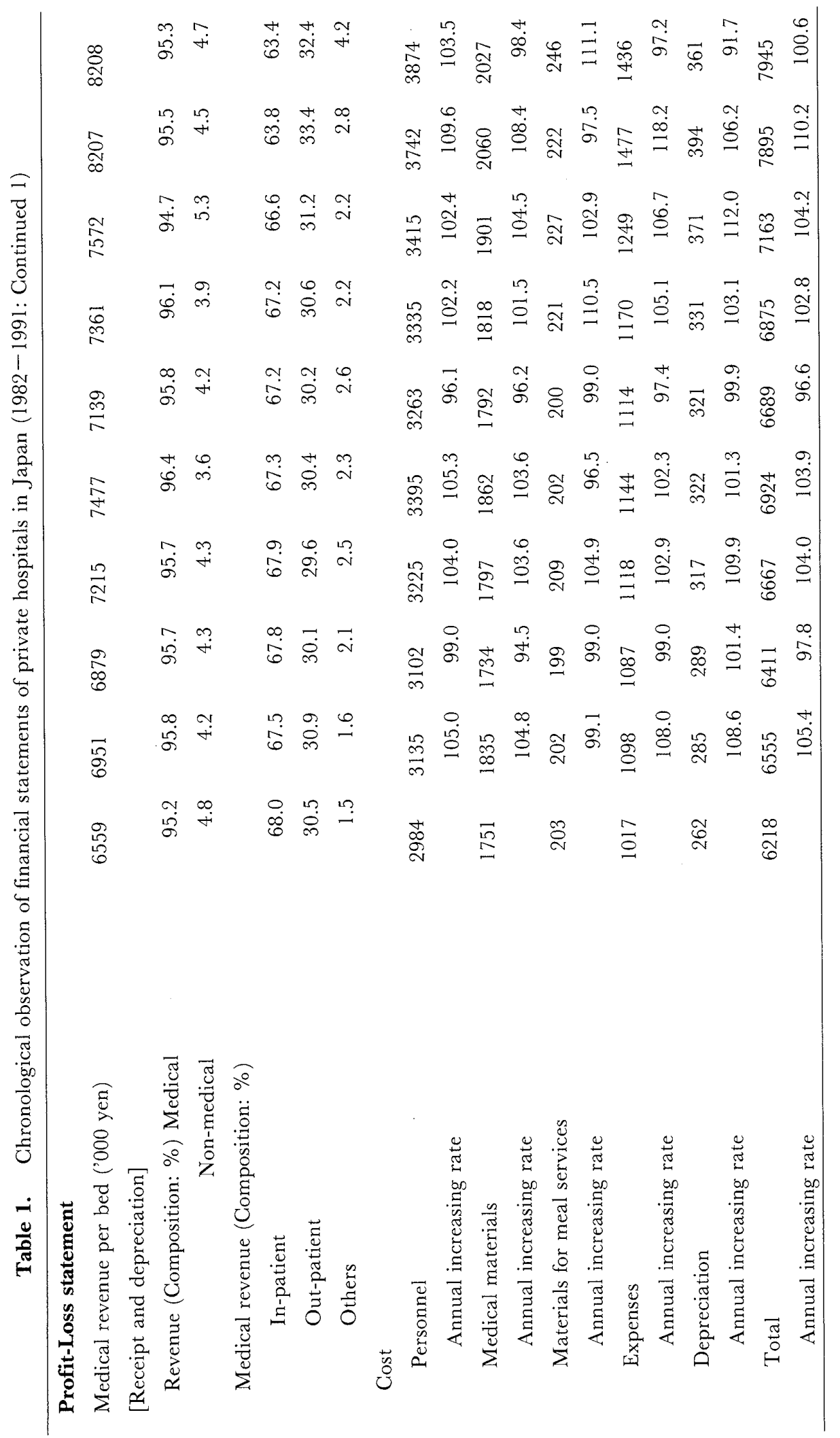




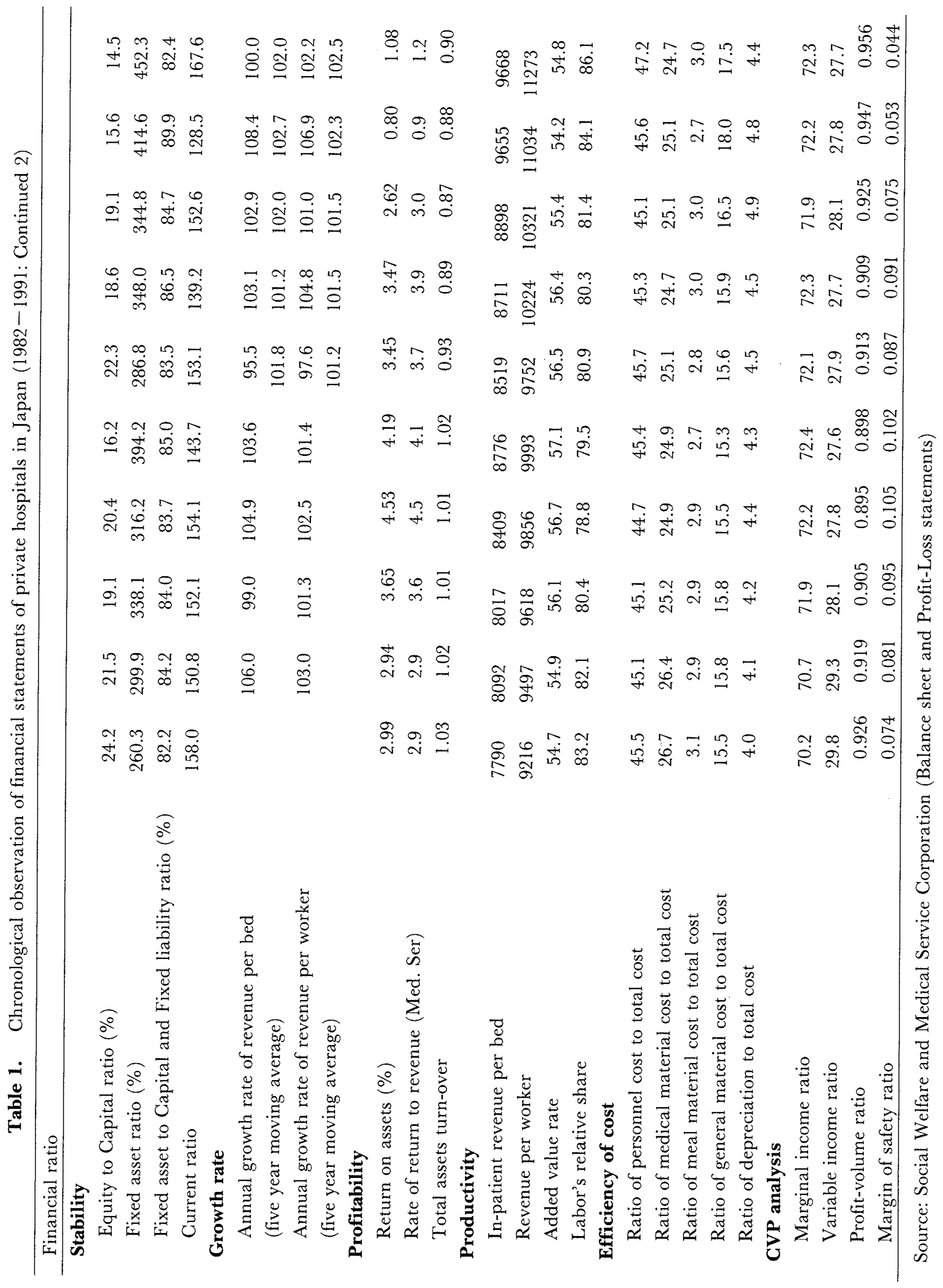


境の 3 つを考えてみる。まず，医療サービ 不提供市場における環境要因としては 1970 年頃より生じてきた若年層での入院受療率の 伸び恼みに加えて，1987 年頃から 65 歳以 上の高齢者の入院受療率の伸び悩み現象が生 じてきたことが重要である [11]，それにも かかわらず，民間病院数と病院一般病床数は 1991 年まで増加を続け，それに対応して病 院一般病床利用率も 1985 年の $83.7 \%$ から 1991 年の $81.9 \%$ と 1.8 ポイント減少し ている [12]。このように 1980 年代以降需 要の減少にもかかわらず，供給量が増大した ことがわが国における近年の民間病院の経営 状況の悪化の大きな要因の一つである.

医療従事者の労働市場に関する環境要因と しては，特にバブル経済時に生じた貨金の高 騰がある.1990 年の対前年賃金伸び率は全 産業平均で $5.4 \%$ と非常に大きな伸び率であ り [13]，人件費率が約 $50 \%$ を占める病院 の場合にはこの影響は特に大きいものであっ たと考えられる。ささらに，1986 年の第 1 次 医療法改正後のいわゆる「駆けこみ增床」, および看護基準に応じた診療報酬制度の整備 の推進などにより, 看護婦需要の増大したこ とが人件費の急增を招き医業経営が圧迫され ることになったと考えられる。

資本市場に関する環境要因としては，バブ ル経済時に一致した施設投資の結果としての 高金利負担の問題があげられる。たとえば, 公定歩合についてみると 1989 年の $3.5 \%$ が翌 1990 年には $7.0 \%$ まで急騰している. そして, マスコミ紙上に病院の倒産等が報じ られるにつれ，病院は「構造不況業種」の一 つとして位置づけられ，銀行等が資金の融資 を躊躇する傾向が生じてきている.

医療材料等の購買市場に関する環境要因と しては，まず診療報酬改正による薬価基準の 引き下げの影響があげられる。本研究におけ る観察期間に拈ける医療費ベースの引き下げ 幅を経時的に観察すると, 途中消費税の導入
に伴い 1989 年に $0.65 \%$ の引き上げがあっ たものの，1981年に $6.1 \% ， 1983$ 年に $1.5 \%, 1984$ 年に $5.1 \%, 1985$ 年に 1.9 $\% ， 1986$ 年に $1.5 \% ， 1983$ 年に $2.9 \%$ ， 1990 年に $2.7 \%$ と一貫して薬価基準の引き 下げが行われている。わが国の医業経営はそ の是非はともかくとして，大きな薬価差益に 依存してきたという歴史的経緯から，この購 買市場での変化が医業経営に与えた影響は非 常に大きい。また，他の材料に関する一般的 物価水準の上昇が医業経営に与えた影響も大 きく，特に，後に述べるようにわが国の診療 報酬改定の基本的ロジックが 1981 年の改定 を機に「物価・賃金スライド方式」から「自 然増控除方式」に転換したことにより，医療 材料等の購買市場の動向は医業経営に大きな 影響を与えるようになっている。

次に、こうした病院をめぐる4つの市場環 境の動向を規定する政治的環境の変化とその 医業経営への影響について述べる。1961 年 の国民皆保険実現以後，わが国の医療サービ 又提供体制は，高度経済成長の追い風と低金 利の融資制度や優遇税制, 診療報酬制度の充 実などの経済的優遇政策により，民間を主体 に急成長した。この量的充実がわが国の健康 水準の向上に貢献したことは疑いもないが, その一方で 1961 年から 1984 年の間の平均 医療費増加率 $19.6 \%$ が示すように, 医療費 の国家財政に対する影響の度合も飛躍的に増 大した [14]．そして，政府はわが国の医療 供給体制は量的にはすでに充足したとして， 質的充実への方向転換を明確化した。具体的 には，わが国のマクロレベルでの医療費の動 向を決定つけりる診療報酬制度の拢本的な改革 と医療法の改正を通じて，医療供給体制の構 造変換を図ることとなる。まず診療報酬に関 しては，Table 2 に示した算定方式のように

「医療機関の医業費用の増加はすべて診療報 酬の引き上げによって補填する」という「物 価・賃金スライド方式」が, 1986 年の改定 
Table 2. Calculation formula of modification rate of the remuneration for medical treatment in the old regime, so called 'General price \& Wage sliding method'

\begin{tabular}{lll}
\hline \multicolumn{2}{c}{ Items to be considered } & \multicolumn{1}{c}{ Corresponded index } \\
\hline 1) Revenue of medical doctors: a 1 & Per capita GNP: bl & $\mathrm{a} 1 \times \mathrm{bl}$ \\
2) Cost for other personnel: a2 & National average of employee's income: $\mathrm{b} 2$ & $\mathrm{a} 2 \times \mathrm{b} 2$ \\
3) Cost for non-medical materials: a3 & Consumer price index: b3 & $\mathrm{a} 3 \times \mathrm{b} 3$ \\
\hline Proposed increasing rate of remuneration for medical treatment & $\sum$ ai $\times \mathrm{bi}$ \\
\hline
\end{tabular}

Source: Hiroi Y (1994)

から「自然増控除方式」に転換された [15]. この方式の基本的ロジックは「医療費すなわ ち医療機関の収入には価格要因以外の自然増 (人口増，高齢化等）という要素が大きく， この部分は改定率から控除して構わない」と いうものである。これにより診療報酬におけ る個々の項目の単価が抑え达まれると同時に， 看護職の配置基準および老人患者収容率基準 により, 近年の医療費高騰の最も重要な要因 である老人入院医療費の包括化が進行し，数 量面でも医療費抑制の仕組が構築されている. こうした流れのなかで，民間の一般病院は費 用負担の少ない老人病院あるいは老人保健施 設への構造転換を迫られているといえる，特 に，今後計画されている公的介護保険の導入 によって，もし，療養型病床群，老人病院， 老人保健施設，特別養護老人ホームが同等に 処遇される状況が実現すると，この構造転換 は大きく加速されることが予想される。また， 人口あたり病床数と入院医療費との間に強い 相関があることは明らかであるが，これにつ いても地域保健医療計画により病床過剩地域 での増床は不可能となり，規模拡大による私 的病院の発展は大きく制限されることとなっ ている.

政治的環境条件の背景要因となっている社 会的・文化的環境要因については，患者の権 利意識の高揚とニーズの多様化が指摘できる. 国民の高学歴化と社会の情報化により，今日 患者のもつ医学知識は高度化しており，それ に伴い治療内容の十分な説明と同意，療養環
境のアメニティの向上への要求など，患者の 権利意識の高揚とニーズの多様化が進んでい る. それにともない医事訴訟の増加と補償額 の高騰が生じており，医療機関におけるリス クマネジメントの必要性が高まっている。さ らに重要なことは，このような一般社会にお ける雲囲気が医療機関への潜在的不信感を増 大させることで，例えば医業経営改善のため の政策（例えば，診療報酬の引き上げ）への 国民の同意が得られにくくなることの可能性 があることである。一部医師による乱診乱療 や製薬会社との癒着による医師の不正な収入 などに関するマスコミ報道がこうした傾向を 強めることが危惧される。

以上のような外部環境要因の変化に起因す る諸問題に加えて, 病院内部の要因, 特に合 理的医業経営の不在が今日の医療経営状況の 悪化に関係していることも事実である．わが 国の医療機関の一般的発展過程は，診療所か ら小規模病院，中・大規模病院への規模拡大 と表現される。このために経営と医療サービ スの提供とが分離されず，院長である医師の 方針により医療経営が左右され，経営的側面 より医療的側面が強調されてきた傾向は否め ない。また，マーケティング活動の欠落のた めに，医療提供者の思い描く医療サービスは 地域住民のニーズと必ずしも一致せず，この ことがまた経営状況を悪化させる要因となっ ていると考えられる。第一次医療法改正を機 に，全体的な受療率が伸び悩んでいるにもか かわらず，駆け込み増床が起こり，その結果 
として医業経営が悪化している事実はこのよ うな事情を傍証している。しかし，その一方 で少なから数の良心的な医療機関が困難な 経営状況にあることも，また事実であり，こ のような状況を改善するために，今後具体的 な政策が展開されていく必要がある。 そして, そのためにはまず病院経営の現状が公開され る必要があり，その公開された情報の分析を 通して，今後の施策の方向性が議論される必 要がある。現行のシステムでは，各医療法人 は病院会計準則に基づいて財務諸表を作成し， それを県に提出することとなっているが，そ の情報はこれまでのところ公開されていない. 病院経営の実態を踏まえた診療報酬政策の運 営が，国民の同意のもとで行われるためには, 少なくとも県単位，できれば二次医療圈単位 での域内の施設の経営状況の平均值の公開が 望まれる。また，わが国の医療保障の公的性 格の強さを考えると, 公認会計士, 税理士等 による医療機関を対象とした外部監査および 税務調查がより積極的に行われることが必要 であり，その情報についても公開されること が望ましいと考えられる。

最後に, 一方で病院経営の合理性が追及さ れ，他方で住民の医療サービスへのニーズが 多様化している現状を考慮すると，医師が診 療の傍らで医業経営を行うことはもはや不可 能に近い状況になっていると考えられる。し
たがって，医師が自分の望む医療サービスを 提供し，しかもそれが住民のニーズにも適合 するためには，医師の希望をくみ取りながら それを経営学的合理性の基で可能にする病院 経営の専門家の体系的な養成が，わが国にお いても, 大学や大学院等で行われる必要があ る，例えば，著者の一人が学んだフランスの 国立公衆衛生学校では, 3 年間の病院管理職 の養成課程があり, 大学の法学部, 経済学部 等を卒業した学生が病院での実務経験の後, この課程に入学し, 専門的な訓練を受けてい る. フランスの公的病院の場合, この課程を 修了することが病院長になるための資格要件 であり，その教育課程は非常に厳しいもので あった。が国の場合，このような病院長に なるための資格要件を設定することの必要性 はないと思われるが，病院経営の専門家を養 成するための課程が大学や大学院レベルで設 置されていくことが，ミクロレベルで合理的 病院経営を可能にするためのみならず，マク ロレベルで望ましい医療サービス提供システ ムを構築するためにも今後必要であると思わ れる。

\section{謝 辞}

本研究を行うにあたり貴重な参考資料を提 供していただいた社会福祉・医療事業団の関 係各位に深謝する。

\section{引用 文 献}

1. 厚生省大臣官房政策課（1994）：21 世紀福祉ビジョン一少子・高齢社会にむけて一，第 一法規，東京 $\mathrm{p} 8$

2. 西村周三 (1995)：社会共通資本としての医療制度。(宇沢弘文，国則守生，編）。制度資 本の経済学. 東京大学出版会, 東京 pp 89-107

3. 社会保険研究所（1993）：[動向］厚生省初の民間病院経営緊急調查まとまる。社会保険 旬報 $1814: 16-22$

4. 医業経営研究会 (1995) : 新しい医業経営. 日本医師会編, 国民医療年鑑平成 6 年度版. 春秋社，東京 pp 344-385

5. 社会福祉・医療事業団 (1992)：病医院の経営分析参考指標.

6. 佐藤裕一（1994）：ビジュアル経営分析の基本．日本経済新聞社，東京 $168 \mathrm{pp}$

7. 川渕孝一（1995）：これからの病院マネジメント。医学書院，東京 pp 211-272 
8. 藤原欣一郎 (1994)：経営分析論の理論と実務. 森山書店, 東京 pp 82-83

9. 中央社会保険医療協議会（1993）：医潦経済実態調査。

10. 川渕孝一 (1995)：ibid. pp 68-89

11. 厚生省大臣官房統計情報部編（1994）：平成5年患者調查，厚生統計協会，東京

12. 厚生省大臣官房統計情報部衛生統計課（1992）：日本の患者と医療施設. 厚生統計協会, 東京

13. 広井良典（1994）：医療の経済学．日本経済新聞社，東京 p 54

14. 厚生省大臣官房統計情報部編（1994）：平成4年度国民医療費，厚生統計協会，東京

15. 広井良典 (1994）：ibid. pp 93-126

\section{付録 財務指標について}

本研究で用いた主な財務指標の計算式を以下に示す.

1. 自己資本比率：(自己資本 $/$ 総資本) $\times 100(\%)$

2. 固定費率：(固定資産／総資本) $\times 100 （ \%)$

3. 固定長期適合率：(固定資産／（自己資本＋固定負債）） $\times 100 （ \%)$

4. 流動比率：(流動資産／流動負債） $\times 100 （ \%)$

5.1床あたり医業収益増加率：(当期 1 床あたり医業収益／前期 1 床あたり医業収益） $\times 100$ (\%)

6. 職員 1 人あたり医業収益堌加率：(当期職員 1 人あたり医業収益／前期職員 1 人あたり医業 収益） $\times 100(\%)$

7. 総資本医業収益率：(医業利益／総資本） $\times 100 （ \%)$

8. 医業収益対医業利益率：(医業収益／医業利益） $\times 100 （ \%)$

9. 総資本回転率：医業収益／総資本

なお，7，8，903つの指標間には，総資本医業収益率=医業収益対医業利益率 $\times$ 総資本 回転率という関係が成り立っている。

10. 稼働病床 1 床あたり入院収益：入院収益／年間平均稼働病床数

11. 職員一人あたり医業収益：医業収益／年間平均職員数

12. 粗付加価值率：(付加価值／医業収益） $\times 100(\%)$. ただし付加価値＝医業費用一医療材 料費一給食材料費一経費とした。

13. 労働分配率：(人件費 $/$ 付加価值) $\times 100 （ \%)$

14. 人件費率：(人件費 $/$ 医業収益） $\times 100 （ \%$ )

15. 医療材料費率：(医療材料費／医業収益） $\times 100 （ \%)$

16. 給食材料費率：(給食材料費／医業収益） $\times 100 （ \%)$

17. 経費率：（経費／医業収益） $\times 100 （ \%)$ ）ただし，経費＝医業費用一人件費一医療材料費 一給食材料費一減価償却費

18. 減価償却費率：(減価償却費／医業収益） $\times 100 （ \%)$

19. 限界利益率：1-(変動費／医業収益)。ただし，本分析では，変動費＝医療材料費十給食 材料費とした。

20. 変動費率：変動費／医業収益

21. 損益分岐点比率：(損益分岐点医業妀益／医業収益）×100（\%)。たたし，損益分岐点医 業収益 $=$ 固定費 $/$ 限界利益率

22. 経営安全率： $1=$ 損益分岐点比率キーワード：医療経済，医療経営科学，財務諸表，民間 病院, 日本 
Analysis of Financial Statements of Japanese Private Hospitals (1982-1991)

\section{Shinya MATSUdA' and Hiroshi MURATA ${ }^{2}$}

'Department of Preventive Medicine and Community Health, School of Medicine,

${ }^{2}$ Department of Industrial Health Economics, Institute of Industrial Ecological Sciences, University of Occupational and Environmental Health, Japan. Yahatanishi-ku, Kitakyushu 807, Japan

Abstract: In order to clarify the financial situation of Japanese private hospitals, the financial statements provided by the Social Welfare and Medical Service Corporation were analyzed for the period from 1982 to 1991. The results clarified the low growth rate and low profitability of the Japanese private hospitals, although their financial situation was relatively stable. However, the efficiency of cost has been stalled in recent years and profitability has been declining due to the low turnover rate of capital. According to the GVP analysis, the Profit volume ratio of the investigated hospitals has been increased to the level of $95 \%$. This situation means that, in the current financial situation, more than half of the Japanese private hospitals will go into the red if revenue declines $5 \%$ due to some short term change in the managerial environment.

Key words: health economics, health management science, financial statements, private hospital, Japan.

J UOEH 18(2): 151-164 (1996) 